$+\infty$

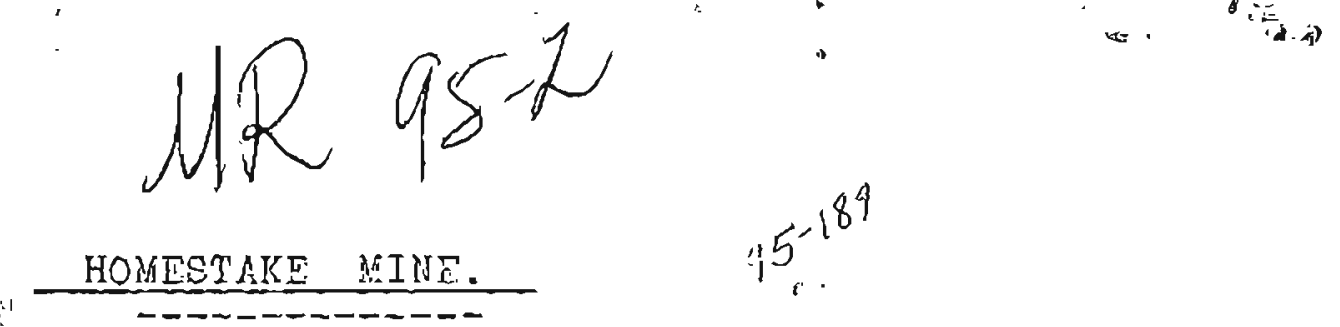

In the following report which is of a prinary nature no atent is made to cover nanes of clainis, area, historiad topography or genersl geology daty, no zamples were taken for sssay purposes but 2 fewirere broken out to show the general character of the ore, these compared well with the ore held tri Valden by Mir. Whalen.

\title{
ACCESSIBILITY.
}

Locoted on the nortin shore of Harriman Fjord no trauble would be encountered in lancirs supplies or machinely from a scow or small bact, sare can be handled by hand no horses being necessury.

\section{SURTAGE OFE}

The surface shoiring $5 \mathrm{far}$ a it is uncovered at this time of the year shows ors in width of 4 lo 8 inches with an exposare in length of about $4 \mathrm{C}$ feet, sanples taken show free gold in nenliy all the crs.

\section{PFESENT EYPLORATION.}

The first tunnel ariven is juagea to be at an elevation of une hundred feet not more than one hundred and ten feet at the rost and was axiven on the veir about 200 feet. This irift shows ore of working value for aoout 40 feet, the balance is either a stringer or broken of little value to the mine unless atoping should locate otber shoots of ore not exposed at present. The ract of this srift is in broken ground and frolls 321 indicatione this shoot boes not exterd on this level. 30 feet of this ore is of very roos character snd can be mined to advantage.

\section{WINZI.}

From the upper tunnel a winze was ounk 64 feet and ore was obtained at all times same beire from 4 inches to 20 inches, samples taken from this winze in January, 1917 and aroyed for gold at she Granite Mine assay office give the following returns; $31.82--128.84--40.19-$

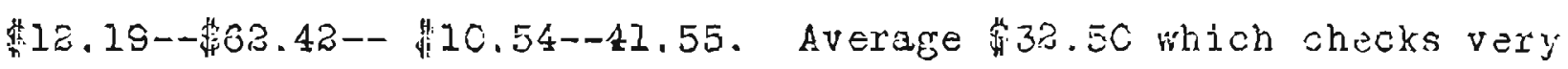
close inith the ore milled on the ground.

The ineer gide of shaft is nuch the strongest and calries the best values sane being closer to the contact. 


\section{LOMPIA TUNEFIL}

This turnel is located about 50 feet fom aboul the present rilll and his developed ore for about seventy five feet, of tinis distance 40 feet is stripped with 35 feet of ore being broken and laying in the tunnel. Average width of this ore is 7 inches and is or a very high grace free gold showing in noarly all of same. The fact of the orlft has 8 inches of ore sire being strong with no indications of being cut out, the values gem to carry up this point equally well. The balance of this ore shoot is proven by the outol side of the winze snd a sriall cross cut near the portal of the tunnel also by the bottom of the winze wich is connected with the lower tunnel. The ore at this level is much stronger and of a better gade than above in the winze.

\section{SUMMAFY OF ORI'.}

From work so done on the vein about 200 ton of cre has been developed that cen be depended on to prove of filling value, this aos not take in any ore thon is above the upper drift or allow for ore below lower tunnel but includes cre than is proven by arift and winze work. A safe estinate would bring the total tonnage up to at least 350 ton which is not a large tonnage but thig rock is sbovis the average value. From the present showing the cre shoot w11l become gomewhat longer extenùing each bioe of the contact and from past experience I would judge this pay ore to extend in depth kelow the present tunnel something like one hunared and twenty feet ith a probable width of 100 feet.

\section{TUTITRE OPTRATIOIS.}

The first work necegsary would be the sinking of a winze and the instaliation of a holst as no depth can be obtained by tunnel wcrk.

The lower tunnel should be iriven until end of ore shoot is found so that stoping operations can be carriea on to advantage. 
Should it be declded that this lease should be taken over a larger mill should be placed on the property witi all necessary power.

A concentrator with a engine large enough to orive sarre, and a crusher are on the ground and will do for a flve gtamp nili.

A smat compressor would have to be placed on the sround to Ingire cheap opartions and to furnish air in case a pump was ured in the winze workings.

One or two bulldings would have to be placed on the riscund and a blacksmith shop put on.

The present mill building is of siall account the lumber used in same being but a few feet.

Wood and timber for all purposes can be reached easily and ater obtained for at least 8 months of the year.

CONCLUSION.

The witer believes that if reasoneble terms can be obtainea and money rajsed to go shesd on the plan outilned with the anount of ore in sight that good leturrs cin be made bearing in mind at all times that it is a lease anoi while small very rich ore. 